\title{
Changing the hierarchical placement of soil moisture regimes in Soil Taxonomy
}

\author{
Mark H. Stolt ${ }^{1}$ (D) | Anthony T. O'Geen ${ }^{2}$ (i) | Dylan E. Beaudette ${ }^{3}$ \\ Patrick J. Drohan ${ }^{4}$ \\ John M. Galbraith ${ }^{5}$ \\ David L. Lindbo ${ }^{6}$ \\ H. Curtis Monger ${ }^{7}$ \\ Brian A. Needelman ${ }^{8}$ \\ Michel D. Ransom? \\ Martin C. Rabenhorst ${ }^{8}$ \\ Joey N. Shaw ${ }^{10}$
}

\footnotetext{
${ }^{1}$ Uni. of Rhode Island, Kingston, RI 02881, USA

${ }^{2}$ Uni. of California, Davis, CA 95616, USA

${ }^{3}$ USDA-NRCS, Sonora, CA 95370, USA

${ }^{4}$ Pennsylvania State Uni., University Park, PA 16802, USA

${ }^{5}$ Virginia Tech Uni., Blacksburg, VA 24061, USA

${ }^{6}$ USDA-NRCS, Washington, DC 20250, USA

${ }^{7}$ USDA-NRCS, Lincoln, NE 68508, USA

${ }^{8}$ University of Maryland, College Park, MD 20742, USA

${ }^{9}$ Kansas State Uni., Manhattan, KS 66506, USA

${ }^{10}$ Auburn, Uni., Auburn, AL 36849, USA
}

Correspondence

Mark H. Stolt, University of Rhode Island, Kingston, RI 02881, USA.

Email:mstolt@uri.edu

Assigned to Associate Editor Ron Reuter

\begin{abstract}
Soil moisture and temperature are incorporated into Soil Taxonomy through the broad classes of moisture and temperature regimes. Although both are important variables in soil formation and land use, soil temperature regime (STR) is typically applied at the family level, whereas soil moisture regime (SMR) is applied at the suborder level. In this paper, we are questioning whether moving SMR to the family level will create a classification system that is more efficient and provide more information to the user at higher categories. The pros and cons of moving ustic, xeric, and udic SMRs from suborder to family category are discussed. To explore this potential change, we used Shannon diversity $(\Delta H)$ as an index of the information gain moving from order to suborder when classifying a soil. The analysis indicated a relatively small $\Delta H$ for most of the country considering current suborder classes. The proposed group of suborders, characterized by diagnostic horizons instead of SMR, conveyed a considerably larger $\Delta H$ supporting a substantial gain in information if the change was incorporated into Soil Taxonomy. The proposed change also has the potential to reduce the number of subgroup taxa by nearly $50 \%$, without losing any of the current information within each taxa. Counterarguments for the change are that SMRs have soil genesis connotations and provide a way to group similar soils on broad-scale maps. A change in the hierarchy of SMRs within Soil Taxonomy could deemphasize the relevance of soil moisture to soil genesis, morphology, and ecology.
\end{abstract}

\section{1 | INTRODUCTION}

Seasonal moisture dynamics is one of the principle drivers of many biological and pedological processes in soils. This knowledge base is generally documented by soil moisture regimes (SMRs) in Soil Taxonomy to inform decision making such as engineering design, cultivation practices, county

Abbreviations: SMR, soil moisture regime; SSURGO, Soil Survey

Geographic Database; STR, soil temperature regime.

(C) 2021 The Authors. Soil Science Society of America Journal (C) 2021 Soil Science Society of America land use zoning, and understanding natural ecosystems (Troeh $\&$ Thompson, 2005). Soil moisture influences the presence, depth, and thickness of many epipedons and diagnostic horizons (Buol, Southard, Graham, \& McDaniel, 2003; Schaetzl $\&$ Anderson, 2005) that are often used as criteria to classify soils. The strong correlation of soils to bioclimatic zones was captured in the concept "zonality" by Dokuchaev and his students in the late 1800s and subsequently incorporated into the early U.S. classification systems in the 1920s and 1930s (Baldwin, Kellogg, \& Thorp, 1938; Marbut, 1935; Simonson, 
1997; Tandarich, Darmody, Follmer, \& Johnson, 2002). Similarly, the authors of Soil Taxonomy incorporated soil moisture into the order, suborder, great group, and subgroup categories using the concept of SMR (Soil Survey Staff, 2014).

The authors of the World Reference Base (IUSS Working Group, 2015), the other international soil classification system, make it clear that "climate parameters are not applied in the classification of soils." Krasilnikov, Ibanez Marti, Arnold, and Shoba (2009) reviewed the Chinese, New Zealand, German, Polish, Hungarian, Romanian, Israeli, Japanese, and South African soil classification systems and reported that only the Chinese used moisture regimes like udic and ustic at the order or suborder level. New Zealand uses "Semiarid" as one of their 15 orders and the Israeli system recognizes Desert Lithosols and Desert Alluvial at the order level (Krasilnikov et al., 2009). All of the systems reviewed by Krasilnikov et al. (2009) identified wet soils at the order level. This is also true for the Australian (Isbell \& National Committee on Soil and Terrain, 2016), Canadian (SCWG, 1998), and English and Welsch systems (Spaargaren, 2000).

In this paper, we examine an idea to move selected SMRs from the suborder to family level within the hierarchy of Soil Taxonomy to test the effect of such a change on Soil Taxonomy. These discussions initiated within the Soil Science Society of America's task force to make Fundamental Changes to Soil Taxonomy (Galbraith, Stolt, Rabenhorst, \& Ransom, 2018). The goal of the task force is to explore changes to Soil Taxonomy to create a less complicated and more user-friendly system that can serve as an effective and engaging tool, and as a way for the soil science community to reach and assist other disciplines and communities that use soils information. The issues to be addressed with Soil Taxonomy are many, but this should not be surprising considering that development of the system began in the early 1950s, and it was adopted for USDA soil surveys by 1965 (Cline, 1979). Throughout the evolution of Soil Taxonomy, a tremendous number of taxa have been added. For example, between 1983 and 2010, over 160 new subgroups were added just within the Inceptisols order (Stolt \& Needelman, 2015). Since 1960, the number of subgroups in Soil Taxonomy has increased 10-fold from 250 to 2,500 (Rabenhorst, 2016). Much of these increases are the result of international committees on Andisols, Anthropogenic Soils, Aquic Moisture Regimes, Aridisols, Taxonomic Families, Low Activity Clays, Oxisols, Permafrost-Affected Soils, Soil Moisture and Temperature Regimes, Spodosols, and Vertisols (Historical International Committee Recommendations, 1975-2013, https://www.nrcs.usda.gov/wps/portal/nrcs/detail/soils/ survey/class/taxonomy/?cid=stelprdb1262263). Although the number of taxa in Soil Taxonomy has grown rapidly as we have learned more about soil classification, there have been relatively few conceptual changes to maintain the original goal of the document as a basic system of soil classification.

\section{Core Ideas}

- Many aspects of Soil Taxonomy need changing for a more efficient system.

- Soil classification could be more efficient if soil moisture regime (SMR) was at the family level.

- SMR at the suborder level provides insight into soil genesis.

- SMR at the suborder level allows for creation of broad-scale maps.

- Soil use decisions may be better served with diagnostic properties at the suborder level.

The issue being debated here is whether moving the SMRs to the family level will streamline the system without losing the valuable information that is held within each taxa. In this paper, we debate the positives and negatives of making this change. There are a range of reasons for both keeping SMR where it currently is at the suborder level and moving it to the family level in the classification system. For the purposes here, we focus on the pros and cons of moving udic, ustic, and xeric SMR identification from suborder to family level. Aridic and aquic SMRs will not be considered in this discussion. Aridic SMR is not uniformly applied across soil orders and is limited to Aridisols and Entisols. Aquic and peraquic SMR are not used for taxa; the aqua formative element is used in taxa (i.e., Aqualfs) to indicate aquic conditions (Soil Survey Staff, 1999). In addition, the aquic and peraquic moisture regimes are being considered part of other fundamental changes at the order level.

\section{2 | ARGUMENTS FOR MOVING SMR TO THE FAMILY LEVEL}

\section{1 | Towards a more efficient and consistent classification system}

Currently in Soil Taxonomy, soil temperature regimes (STRs) are applied primarily at the family level (cryic and gelic are the exceptions because of their severe limitations to soil use). Thus, one advantage of moving SMR to the family level is that it would provide added consistency to the classification system by having both soil climate attributes at this same level in the hierarchy. This makes sense, since soil temperature is already tied directly to the definitions of the SMRs being used to specify when the control sections are either moist or dry. For example, in the definition of the udic moisture regime Soil Taxonomy reads: "If the mean annual soil temperature is lower than $22{ }^{\circ} \mathrm{C}$ and if the mean winter and mean summer soil temperatures at a depth of $50 \mathrm{~cm}$ below the soil surface differ by $6{ }^{\circ} \mathrm{C}$ or more, the soil moisture control section, in 


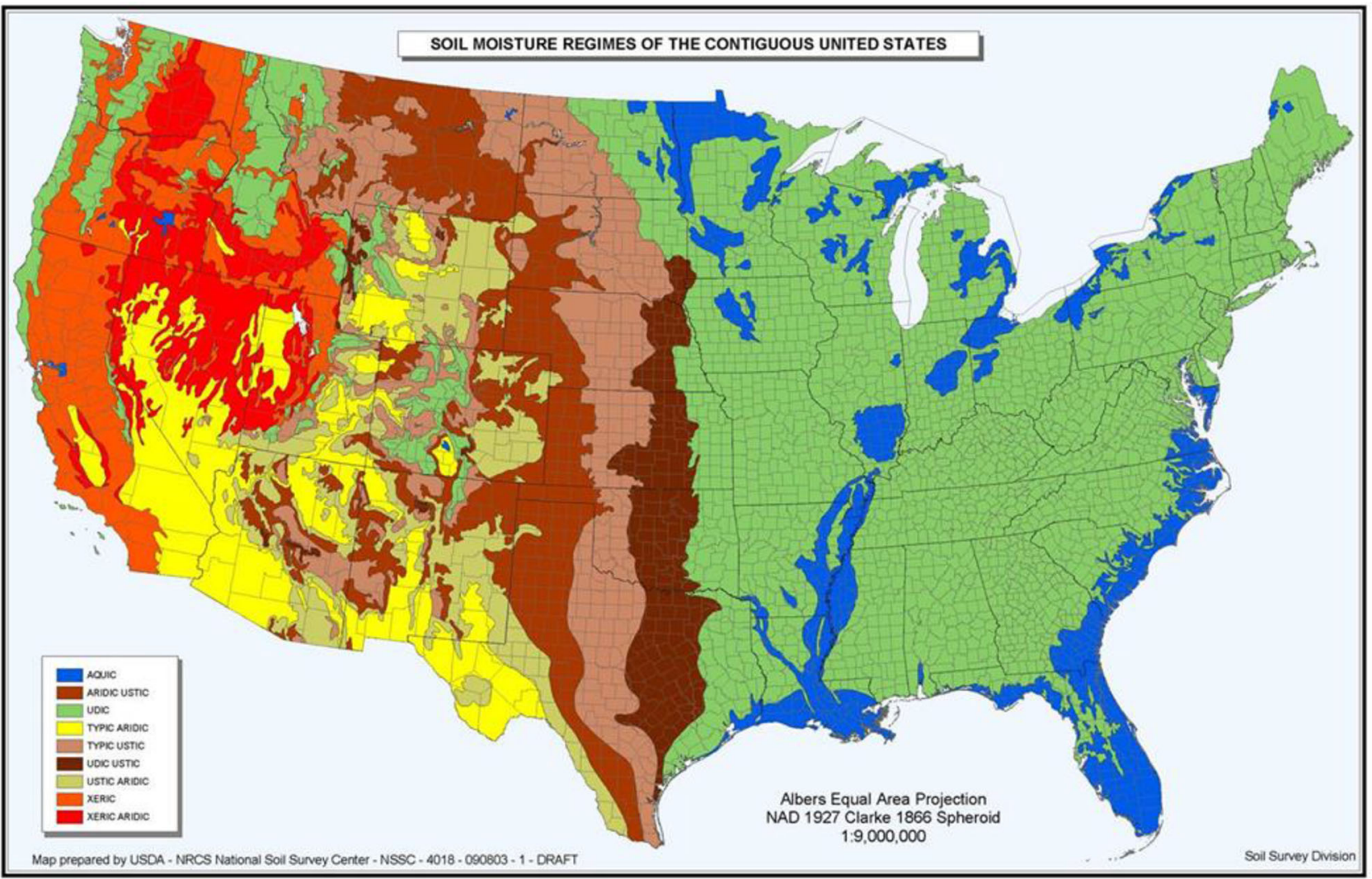

F I G U R E 1 Soil moisture regimes in the United States (https://www.nrcs.usda.gov/Internet/FSE_MEDIA/nrcs142p2_050436.jpg)

normal years, is dry in all parts for less than 45 consecutive days..." (Soil Survey Staff, 2014). Temperature criteria were applied to the SMRs to ascertain whether coldness or dryness controlled the growing season (Smith, 1986, p. 124). The temperature requirements in the udic definition cited above are not uniquely specific to udic. Temperature criteria also apply to xeric and ustic regimes.

Although primarily applied at the suborder level, presently SMR is also applied at the order (Aridisols), great group (e.g., Xerofluvents, Torripsamments, Udifolists, Ustivitrands), and great group/subgroup (e.g., Xeric Torrifluvents, Aridic Ustifluvents) levels. The orders Spodosols and Gelisols do not apply SMR in any taxa. Placing SMR at the family level would ensure that SMR is specified consistently for all soils.

The SMRs discussed here cannot be identified from soil morphologic descriptions. Although easy to measure, soil moisture is not something that is typically monitored in the field for classification purposes because of daily, seasonal, and interannual variability (Salley, Sleezer, Bergstrom, Martin, \& Kelly, 2016). Although soil moisture content is a dynamic soil property, SMR is a class of climatic conditions that define soil moisture distribution and availability throughout a typical year based on long-term (30-yr) averages of measured data. Thus, soil moisture is rarely measured for classification purposes, but rather inferred from climatic data or vegetation, and could be considered a barrier step during classification of soils in the field. The Keys to Soil Taxonomy make it clear that inferring SMRs from climatic data is the expected protocol: "The intent in defining the soil moisture control section is to facilitate estimation of soil moisture regimes from climatic data" (Soil Survey Staff, 2014). Thus, maps based on temperature and precipitation patterns are typically used to determine SMRs (Winzeler et al., 2013), and this process can be efficiently accomplished after soils have been described in the field.

Using SMR at the suborder level is confusing along climatic boundaries. In large parts of Texas, Oklahoma, Kansas, Nebraska, South Dakota, and Montana, SMRs are recognized as borderline or transitional (Figure 1). At present, these borderline SMRs are defined within Soil Taxonomy in selected cases of particular taxa by adding Udic or Ustic at the subgroup level (i.e., Udic Argiustolls). The classification of adjacent soils in different taxa, however, may not utilize (recognize) the borderline case at the subgroup level. For example, in parts of Oklahoma the Lovedale series (Udic Argiustolls) is mapped adjacent to the Dougherty series (Arenic Haplustalfs). In one case, the transitional nature of the moisture regime is recognized, whereas in the other case it is not. Moving the SMR to the family level would allow these transitional soil moisture conditions to be identified in all the soils of these transitional areas. 


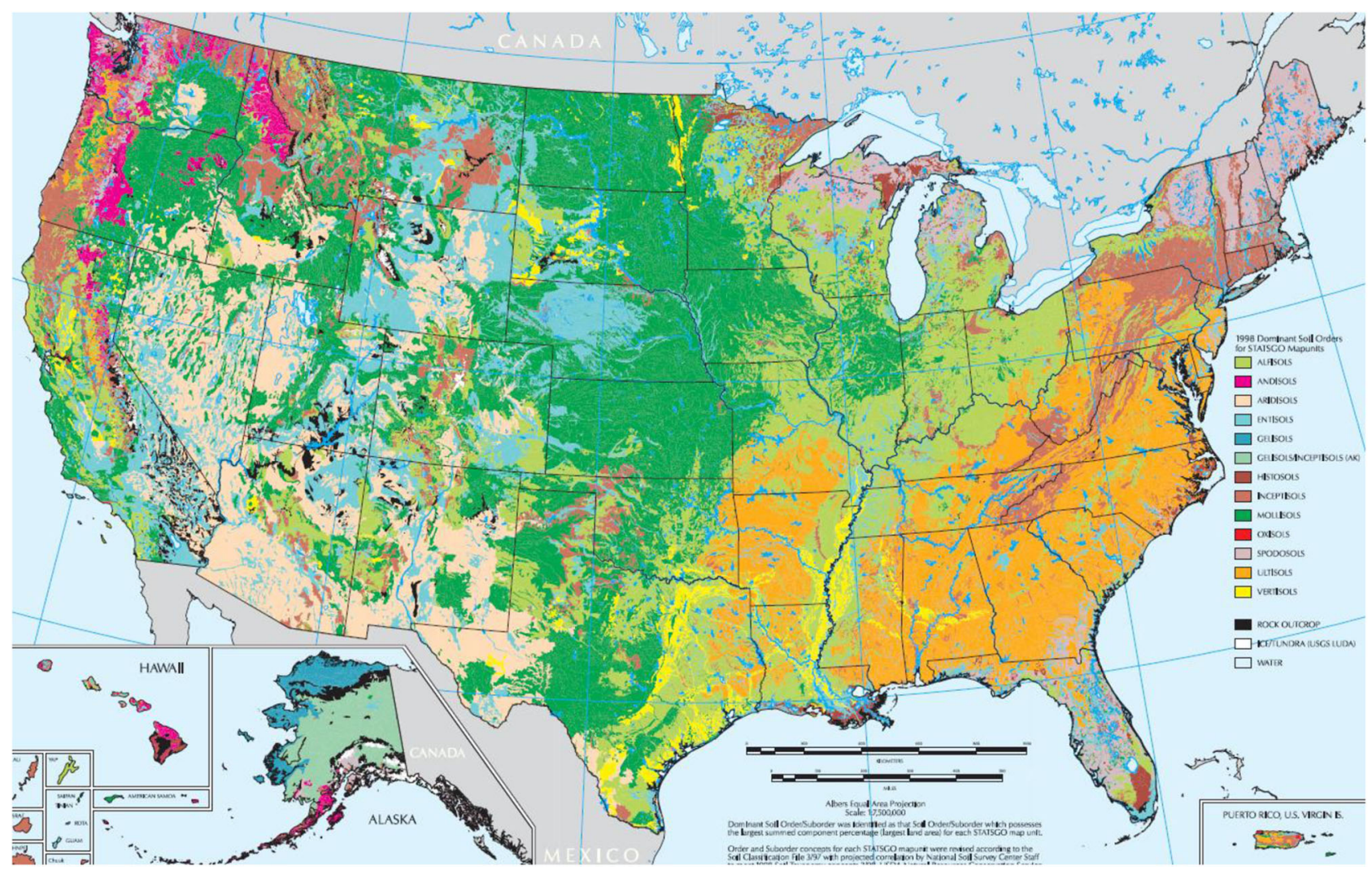

F I G U R E 2 Distribution of soil orders in the United States (https://www.nrcs.usda.gov/Internet/FSE_MEDIA/stelprdb1237749.pdf)

One of the arguments made in this manuscript for keeping SMR at the suborder level is the importance that SMR plays in allowing for the creation of small-scale maps showing broad patterns of important soil properties (e.g., Udults, Ustalfs, Xerepts). We argue here that with the advent of GIS, SMRs are not necessarily needed at the suborder level to convey broad-scale patterns. Continental-scale maps based on soil orders can be an effective approach to relate soil kind with geographic areas. For example, such maps show that very few Mollisols occur in the eastern United States (Figure 2). Using GIS, the SMR layer (Figure 1) can be overlain with the distribution of Mollisols (Figure 2) to show climatic relationships of Mollisols. This offers another way to easily make broad-scale maps of soil taxa. In the first $25 \mathrm{yr}$ of Soil Taxonomy, GIS applications were not available, but now this is how almost all soil maps are currently made. This suggests that for broad-scale mapping of soil climate differences, there is no advantage to having suborders defined by SMR.

The advantage of a dynamic GIS approach to SMR depiction was suggested by Winzeler et al. (2013). These authors used a Newhall-based simulation model (NSM) to develop GIS-based raster grids of SMR and compared these with a traditional analog map of SMR created with expert knowledge coupled with limited climate simulations (Newhall \& Berndanier, 1996). Although the true accuracy of these approaches was not evaluated, the GIS-based approach resulted in a
$76 \%$ agreement with the traditional map with certain transitional areas between moisture regimes presenting most differences. It is evident that with global climate change, increasing temporal and spatial variability of SMRs will occur, and such an approach suggested by Winzeler et al. (2013) may have increased validity to soil classification and mapping in the future. Furthermore, accurate SMR placement using a GIS-based approach can be implemented at any category of Soil Taxonomy, but the potential dynamic nature of SMRs (D'Avello, Waltman, Waltman, Thompson, \& Brennan, 2019; particularly near transitions) warrants its placement at a lower category (i.e., family vs. suborder) where local changes in climate could be documented. This dynamic nature of SMRs cannot be recognized at the suborder level because it would influence too many taxa outside the area where these local conditions apply.

Moving SMR to the family level may provide a more efficient classification process by minimizing the number of taxa that have to be considered in the key prior to reaching the lowest levels of the hierarchical system (family level). This could be visualized by considering examples for Xerepts, Ustepts, or Udepts (Table 1). Each suborder shows redundancy of major diagnostic horizon or characteristic identification at the suborder level by having more than one great group identified with the formative elements Eutr, Hapl, Dystr, Calc, Dur, and Frag (Table 1). There are 184 different subgroup taxa for these 
TA B L E 1 Great groups of Inceptisols in the suborders of Xerepts, Ustepts, and Udepts and the number of subgroups in each great group of the current version of Soil Taxonomy (Soil Survey Staff, 2014). The Fundamental Change Example (FCE) shows possible suborder and great group taxa if soil moisture regime was moved to the family level

\begin{tabular}{|c|c|c|}
\hline Suborder & Great group & $\begin{array}{l}\text { No. of } \\
\text { subgroups }\end{array}$ \\
\hline & Current & \\
\hline \multirow[t]{5}{*}{ Ustepts } & Durustepts & 1 \\
\hline & Calciustepts & 10 \\
\hline & Dystrustepts & 11 \\
\hline & Haplustepts & 23 \\
\hline & Humustepts & 7 \\
\hline \multirow[t]{6}{*}{ Xerepts } & Durixerepts & 6 \\
\hline & Calcixerepts & 7 \\
\hline & Fragixerepts & 5 \\
\hline & Dystroxerepts & 14 \\
\hline & Haploxerepts & 16 \\
\hline & Humixerepts & 11 \\
\hline \multirow[t]{6}{*}{ Udepts } & Sulfudepts & 1 \\
\hline & Durudepts & 5 \\
\hline & Fradiudepts & 5 \\
\hline & Eutrudepts & 22 \\
\hline & Dystrudepts & 23 \\
\hline & Humudepts & 17 \\
\hline \multirow[t]{2}{*}{ Totals: 3} & 17 & 184 \\
\hline & Fundamental Change Example & \\
\hline \multirow[t]{4}{*}{ Dystrepts } & Aquidystrepts & 7 \\
\hline & Lithidystrepts & 2 \\
\hline & Interdystrepts & 8 \\
\hline & Haplodystrepts & 5 \\
\hline Sulfepts & Haplosulfepts & 1 \\
\hline \multirow{3}{*}{ Durepts } & Aquidurpts & 2 \\
\hline & Interdurepts & 2 \\
\hline & Haplodurepts & 2 \\
\hline \multirow[t]{3}{*}{ Fragepts } & Aquifragepts & 4 \\
\hline & Interfragepts & 3 \\
\hline & Haplofragepts & 1 \\
\hline \multirow[t]{3}{*}{ Eutrepts } & Aqueutrepts & 3 \\
\hline & Intereutrepts & 17 \\
\hline & Hapleutrepts & 8 \\
\hline \multirow[t]{4}{*}{ Humepts } & Aquihumepts & 3 \\
\hline & Lithihumepts & 1 \\
\hline & Interhumepts & 6 \\
\hline & Haplohumepts & 6 \\
\hline \multirow[t]{2}{*}{ Calcepts } & Aquicalcepts & 1 \\
\hline & Lithicalcepts & 2 \\
\hline
\end{tabular}

T A B L E 1 (Continued)

\begin{tabular}{|c|c|c|}
\hline Suborder & Great group & $\begin{array}{l}\text { No. of } \\
\text { subgroups }\end{array}$ \\
\hline & Intercalcepts & 5 \\
\hline & Haplocalcepts & 4 \\
\hline Totals: 7 & 24 & 93 \\
\hline
\end{tabular}

Note. The example uses all the currently defined taxa. Aqui, Lithi, and Haplo great groups are those currently defined as Aquic, Lithic, and Typic subgroups. Intergreat groups (e.g., Interdystrepts) are defined as those soils with significant evidence of pedogenesis besides a cambic horizon (e.g., a weakly developed spodic horizon, Spodic Interdystrepts). Subgroup formative elements for the FCE include Fragic, Fluvic, Psammentic, Spodic, Andic, Humic, Epi, Endo, Vertic, Vitrandic, Lamellic, Alfic, Ultic, Entic, Oxic, Oxyaquic, and Typic.

three suborders. Moving the xeric, ustic, and udic moisture regime to the family level means new suborders need to be created. As previously discussed, this can be done by moving important soil property information currently at the great group level higher in the classification process. In our proposed move of the SMR to the family level (Table 1), new suborders of Sulfepts, Durepts, Fragepts, Eutrepts, Humepts, Calcepts, and Dystrepts were created. In this example, great groups were divided into Aqui, Lithi, and Haplo great groups that match those currently defined as Aquic, Lithic, and Typic subgroups. The example also includes "Inter" great groups (e.g., Interdystrepts). These great groups represent intergrades, those soils with evidence of pedogenesis moving toward something more than a cambic horizon in this case. For example, soils with a weakly developed spodic horizon at the subgroup level would be classified as Spodic Interdystrepts.

The current number of great group and subgroup taxa under the Xerept, Ustept, and Udept suborders is 201 (Table 1). The Fundamental Change Example has only 117 taxa at the great group and subgroup level. Other orders such as Alfisols, Andisols, Vertisols, Mollisols, Oxisols, and Ultisols all have similar redundancy at the great group level from using xeric, ustic, and udic suborders. Thus, there is the potential for similar reductions in the number of taxa at the subgroup level for these orders too.

Our example clearly shows that changes in hierarchical placement can be made in Soil Taxonomy that would make suborder taxa more meaningful in regard to diagnostic soil properties while at the same time effectively reducing the number of taxa at the subgroup level. One concern of those opposed to moving SMR to the family level is that with moving great group properties to the suborder level there will be little information gain between great groups and subgroups (see below). It is noted in Table 1 that for the Aquidystepts there are eight subgroups. As proposed, these subgroups include Fragic, Densic, Humic, Psammentic, Spodic, Fluvic, Andic, and Typic. In a udic moisture regime under the present hierarchy, all these soils are classified as Aquic Dystrudepts. With the moisture regime at the family level, considerable 


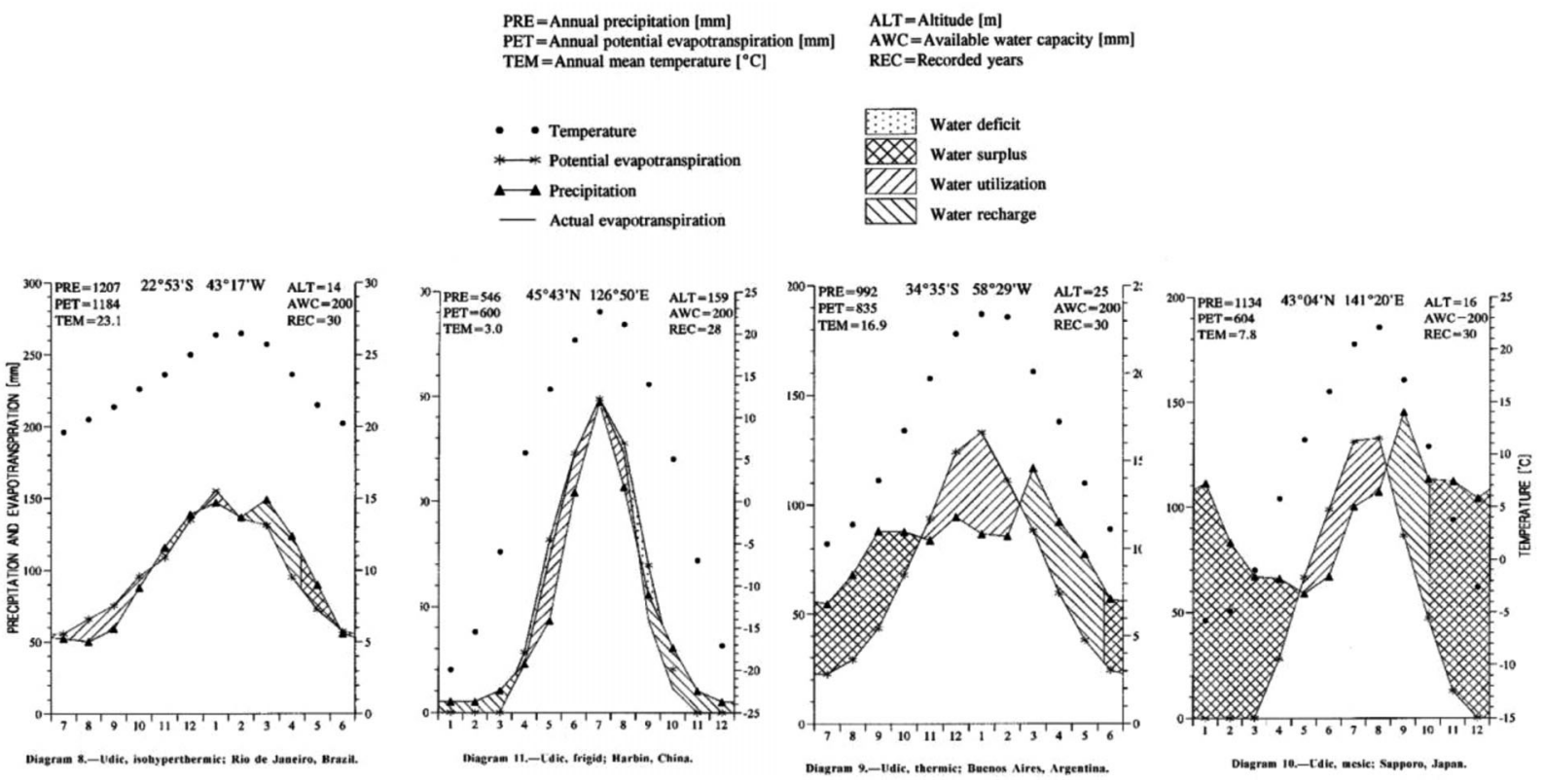

F I G U R E 3 Soil moisture parameters for representative locations within a Udic soil moisture regime (SMR) from Soil Taxonomy (Soil Survey Staff, 1999, pp. 98-100). The graphs were developed using a Thornthwaite approach utilizing averages of monthly temperature and precipitation, and estimated potential evapotranspiration (PE) values (Soil Survey Staff, 1999;

https://www.nrcs.usda.gov/Internet/FSE_DOCUMENTS/nrcs142p2_051232.pdf)

additional soils information (e.g., depth to densic contact, organic-rich epipedons, fragic soil properties) could be added at the subgroup level that is not presently identified.

\section{2 | Conveying the most relevant information}

Few specific decisions regarding soil water management can be made with knowledge of SMR. To illustrate this point, Figure 3 (taken from Soil Taxonomy; Soil Survey Staff, 1999) provides four examples of locations with udic SMRs. These graphs were developed using a Thornthwaite approach using average monthly temperature and precipitation, and estimated potential evapotranspiration values (Soil Survey Staff, 1999). Based on these averages, estimations of water deficit, surplus, utilization, and recharge were calculated. It is evident from these graphs that a wide range in the amount of water utilization exists within a udic SMR among these four locations. Therefore, although broad depiction of soil moisture status can be developed from SMR knowledge, minimal specific information (e.g., irrigation management during growing season) is relayed in udic conditions. Similar variations are illustrated for ustic and xeric in Soil Survey Staff (1999, pp. 101-102). In addition, recent research in Idaho along moisture gradients (Harvey, 2020) indicated that as presently defined, SMR did not align with vegetative communities in the Pacific Northwest. For example, of the 12 sites that were predicted to be xeric based on vegetation, not a single one met the xeric requirements. As such, it is likely that the introduction of diagnostic horizons and/or properties at the suborder level instead of SMRs would increase specific soil information needed for land management considerations.

Most land users understand the local climatic constraints. There is a vast body of knowledge about soil moisture in the hands of growers, especially at the local level where climatic data are too coarse. A criticism for using SMR at the suborder level is that no information about the nonclimatic soil properties is gained moving from soil order to suborder. To test this, we calculated the relative information gain between the order and the suborder level across the contiguous United States based on the current classifications (SMR at the suborder level) and then again using a proposed suborder modification. The proposed suborder classifications were based on diagnostic horizons. For example, in the case for Inceptisols, information gain (from order to suborder) was evaluated through a comparison of current suborders Xerepts, Ustepts, or Udepts with proposed suborders of Inceptisols such as Calcepts, Fragepts, Durepts, Humepts, and so on (Table 1). We used Shannon diversity (Legendre \& Legendre, 1998) as an index of taxonomic diversity and information content (Guo, Gong, \& Amundson, 2003; Shannon \& Weaver, 1949). The FY2020/2021 snapshot of the detailed Soil Survey Database (SSURGO) for the conterminous United States (Soil Survey Staff, 2020) was used as the basis for calculating Shannon diversity (hence abbreviated as $H$ ) within $0.5^{\circ} \times 0.5^{\circ}$ grid cells. The area of a $0.5^{\circ}$ cell varies with latitude, decreasing towards the poles. Within the continental 


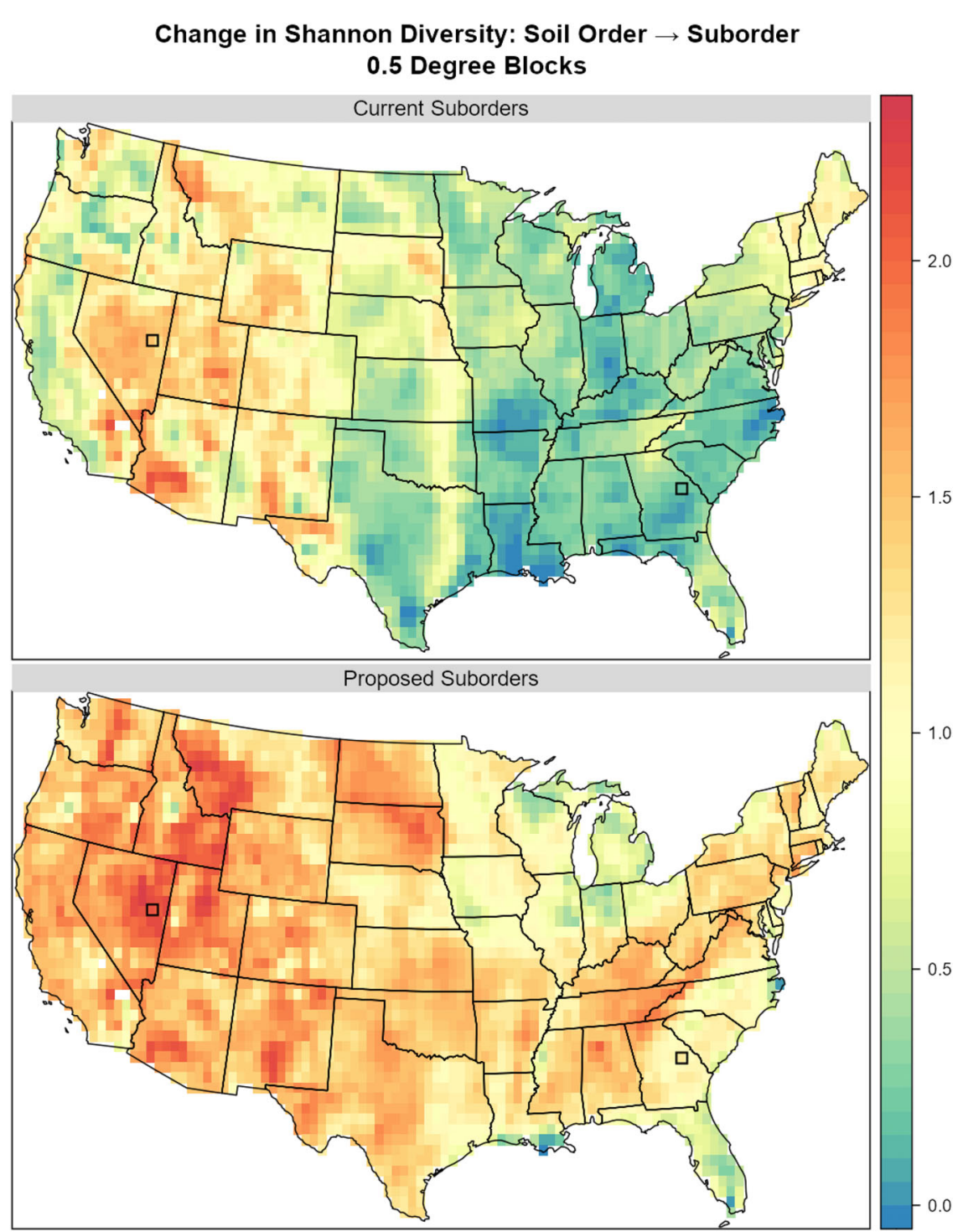

Source: FY2020 SSURGO (non-aqu* suborders)
F I G U R E 4 Change in Shannon Diversity $(\Delta H)$ within $0.5^{\circ}$ grid cells, from the order to the suborder level across the contiguous United States for the current suborder classifications (upper panel), and those of the proposed using diagnostic horizons (lower panel). Maps have been warped to an Albers equal area coordinate system for clarity. The "Aqu" suborders (e.g., Aquults) were not included. The approach illustrated in Table 1 was used for the Inceptisols, Alfisols, Andisols, Vertisols, Mollisols, and Ultisols orders where moisture regime is used at the suborder level. Square symbols represent "western" and "eastern" exemplars of degrees of changes
United States, the approximate area of a $0.5^{\circ}$ block varies from 2,043 to $2,780 \mathrm{~km}^{2}$ with a median value of $2,461 \mathrm{~km}^{2}$ (roughly 608,000 acres). For the analyses,

$$
H=-\sum_{i}^{n} p_{i} \log _{2}\left(p_{i}\right)
$$

where $H$ is the Shannon diversity within each grid cell, $n$ is the number of taxa within each grid cell, and $p_{i}$ is the area proportion for taxa $i$ within each grid cell (sums to 1 across all taxa):

$$
p_{i}=\frac{\log _{10}\left(a_{i}\right)}{\sum_{i}^{n} \log _{10}\left(a_{i}\right)}
$$

where $a_{i}$ is the total area of taxa $i$ within each grid cell:

$$
a_{i}=\sum \operatorname{taxa}_{i} \times \text { comp_pct }_{i}
$$

with $\operatorname{taxa}_{i}$ representing the area of each instance of taxa $i$ within each grid cell and comp_pct ${ }_{i}$ representing the component percentage $i$ within each grid cell as converted to a fraction. The change in Shannon diversity $(\Delta H)$ was computed as $H_{\text {suborder }}-H_{\text {order }}$ for both current and proposed suborders.

For this exercise, we used the approach illustrated in Table 1 for Inceptisols, Alfisols, Andisols, Vertisols, Mollisols, and Ultisols where SMR is currently used at the suborder level. The $\Delta H$ maps (Figure 4) represent the change in Shannon diversity within each grid cell. The computed values are interpreted as an index of "soil information" encoded within various levels of Soil Taxonomy. Ideally, $\Delta H$ values within each cell will increase as one moves from soil order to suborder. That is to say, we would expect that there should be a substantial increase in "soil diversity" provided by Soil Taxonomy per unit area as one moves from higher to lower levels within the hierarchy. 


\section{Change in Shannon Diversity: Soil Order $\rightarrow$ Suborder 0.5 Degree Blocks}

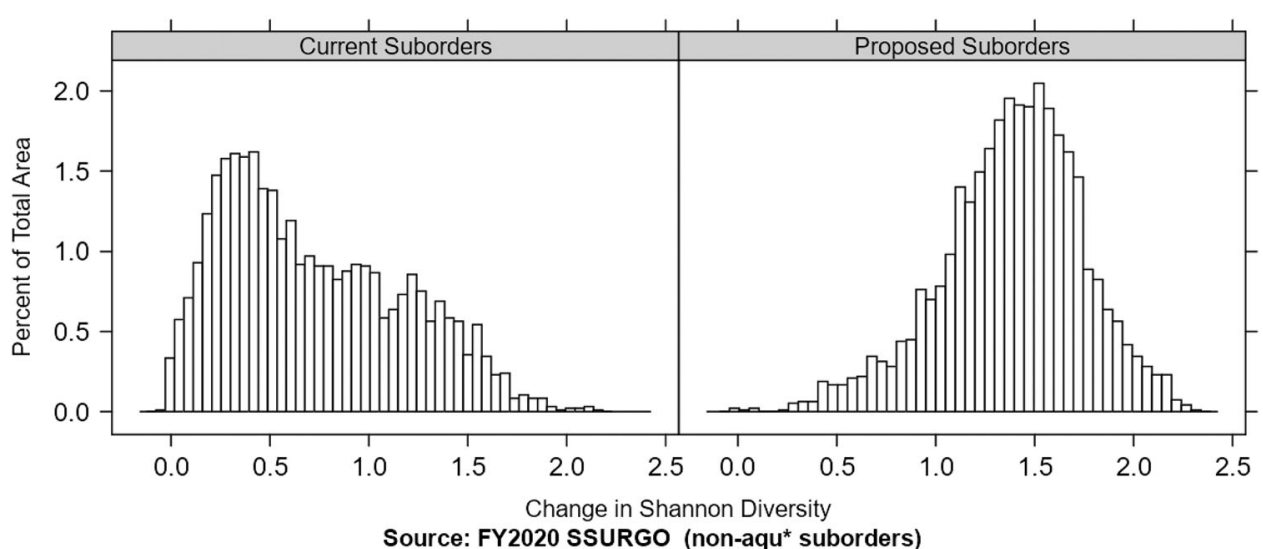

F I G U R E 5 Histograms (50 bins) representing the distribution of $\Delta H$ over all $0.5^{\circ}$ grid cells, computed using the current and proposed suborders. The percentage is that of the total area of the contiguous United States. The median $\Delta H$ is 0.6 for the current suborders and 1.4 for the proposed suborders

Under the current taxonomic system, throughout much of the eastern United States and large parts of Texas, Oklahoma, and North Dakota, $\Delta H$ values are generally $<0.5$ and approaching zero as indicated by the yellow and blue color patterns (Figure 4, top panel). In the Shannon diversity index, values are relative to what is being compared with zero indicating there is no diversity or information content (Ricotta \& Szeidl, 2006; Shannon \& Weaver, 1949). Overall, the distribution of $\Delta H$ values for the current suborder classification for the conterminous United States is skewed toward zero with a median $\Delta H$ of 0.62 (Figure 5). These low values are interpreted to be indicative of little additional soil information conveyed between order and suborder levels using the current SMR classification elements at the suborder level, especially for those areas east of the 100th meridian (over half of the conterminous U.S. land area). In contrast, under the proposed suborder structure (moving SMR to family), in general, the $\Delta H$ increases $1.5-3$ times relative to the current suborder classification values, even for many of the areas west of the 100th meridian (Figures, lower panel). Overall for the proposed classification, the median $\Delta H$ is 1.4 and distribution of $\Delta H$ values is more balanced and slightly skewed toward a value higher than the median (Figure 5), suggesting that considerable additional information was provided between the order and suborder levels using the proposed suborder classification approach.

Two example grid cells were selected to demonstrate the Shannon entropy calculation and $\Delta H$ results in a xeric/aridic, "western" (39.5 lat., $-115.0^{\circ}$ long.) context, and in a udic "eastern" (33.0 lat., $-82.5^{\circ}$ long.) context (Figure 4). The "western" example grid cell is predominantly Mollisols (42\% by area) and Aridisols ( $38 \%$ by area), and the "eastern" example grid cell is predominantly Ultisols ( $71 \%$ by area)most of which are Udults ( $54 \%$ by area). There are 79 subgroup taxa within the "western" grid cell and 37 within the "eastern" grid cell. Most of the differences are due to the dominance of a single SMR (udic) within the "eastern" grid cell vs. multiple SMR (xeric, aridic) and STR (thermic, mesic, frigid, and cryic) within the "western" grid cell. The $\Delta H$ (Figure 4) for current suborders was calculated as 1.47 ("western") and 0.17 ("eastern"), and $\Delta H$ for the proposed suborders was 2.10 ("western") and 1.22 ("eastern").

The way soil survey information is accessed today is much different than when the 7th Approximation was first applied to soil surveys in the 1960 s, or even when the official system was published in 1975. Few knew what GIS was, no one had a laptop or tablet, and smartphones were still $25 \mathrm{yr}$ away. Today, we use smartphones or tablets in the field, with the use of a simple soil survey application (https://casoilresource. lawr.ucdavis.edu/gmap/), to find the soil type or types associated with the map unit at our location. With a click or two we have the soil classification of the predominant component. This can be a powerful tool for use and management and for teaching the use of Soil Taxonomy to more than just a few pedologists. More and more farmers are using precision agriculture and managing on a mapping unit by mapping unit basis. At the field level, SMR is not directly relevant to these farmers. However, soil attributes such as water table level or depth to restrictive layers are much more important. In an afternoon, agronomy, ecology, and geology students can be introduced to the basic concepts of soil classification and how that information is easily accessed in the field on their phones. Those students cannot learn everything about 
soils in an afternoon, but they can learn the basic concepts of the suborders (and maybe even great groups) that they could encounter. For an Ustoll, the information gained by these students is limited to an understanding that for these soils there is likely not enough soil moisture to support trees. In contrast, explaining that the suborder classification indicates that the soil has a duripan (i.e., Duroll) or calcic horizon (Calcoll), and showing them the horizons will impress upon them the advantages of understanding soil survey and Soil Taxonomy for use and management. Such students could then easily look up the implications of a duripan or calcic horizon on their tablet or smartphone.

\section{3 | ARGUMENTS TO KEEP SMR AT THE SUBORDER LEVEL}

\subsection{A hierarchical classification system}

In hierarchical classification systems such as Soil Taxonomy, higher level classes carry the most general information to characterize broad groups, and as you move down the hierarchy, unique details further differentiate classes. Soil Taxonomy was designed to be a multicategory system, with a few taxa in the highest categories and a large number in the lowest categories (Smith, 1963), similar to biological taxonomy (kingdom $\rightarrow$ phylum $\rightarrow$ class $\rightarrow$ order $\rightarrow$ family $\rightarrow$ genus $\rightarrow$ species). There are $>25,000$ soil series (lowest level) in the United States, whereas there are 12 soil orders (highest level). The broad groups are subdivided based on the presence of diagnostic features and conditions such as an argillic, natric, or calcic horizon, depth to bedrock, SMR, and mineralogy. Consequently, statements about general properties are made at the order and suborder levels. Having SMR at the suborder level allows the system to communicate that associated diagnostic features at lower hierarchical levels "share" and are unique to a specific climatic environment (SMR). Such taxa can be shown on broad-scale maps (e.g., 1:7,500,000). In contrast, statements about specific properties needed for land use decisions are made at lower levels where soil map units are more homogeneous (Cline, 1963; Riecken \& Smith, 1949), and these map unit delineations are best shown on detailed maps (1:24,000) (Smith, 1986).

To understand the placement of SMRs high in the hierarchy, it is important to point out the difference between "connotative" and "denotative" in classification systems. Denotative definitions are limited to exact, literal criteria. Connotative definitions go one step beyond the literal meaning and give a broader understanding of accessory characteristics. Connotative definitions provide environmental context and insight about not only what taxa exist based on their denotative definitions, but why - pedologically speaking - they exist based on their connotative meaning. It makes connotative sense that
Udalfs generally do not have calcic horizons, but the Ustalfs do.

Moving SMRs to family level of Soil Taxonomy could disrupt some of the hierarchical continuity of the system. For example, the current placement of SMR for many orders allows the classifier to communicate that classes lower in the hierarchy are a result of governing processes linked to soil moisture. Soil moisture regime often serves the function in classification of providing a general grouping (based on management and controls on pedogensis) through which more specific characteristics can further differentiate classes. From a pedogenic perspective, the concept of SMR highlights that soil characteristics driven by seasonality in wet and dry conditions (e.g., xeric or ustic) vs. uniformly moist conditions (udic) are fundamentally different. In support of this perspective, soils with udic SMRs do not have salic or gypsic horizons and ustic SMRs lack fragipans.

A reason to keep SMR at higher levels in the classification system is the effect soil moisture has on the soil environment, both as a soil property and a soil-forming factor. Pedogenic processes are a function of available soil moisture and soil moisture content. Since early in the conception of soil science, climate has been recognized as one of the five state factors of soil formation (Jenny, 1941). Processes that drive the translocation of soil constituents such as presence, thickness, and depth to argillic horizons and/or pedogenic carbonates are often moisture dependent. These relationships can be seen in a transect east to west across Texas (Texarkana to El Paso) where, as the soil moisture status decreases, the soils change from Hapludults, to Calciustalfs, to Petrocalcids and Haplocalids (Bureau of Economic Geology, 2008). Soil moisture is a soil property in the same sense that percentage organic $\mathrm{C}$, clay, or base saturation are soil properties. It is widely agreed among these authors that soil moisture is an important factor, and this factor, like parent material, can be shown on a separate map. Other pedologists hold that SMRs, which represent a range of soil moisture or degree of saturation, can be viewed as a property and soil-forming factor. In the pedogenic paradigm shown below (Targulian \& Goryachkin, 2004), SMRs occur twice:

$$
\text { Factor } \rightarrow \text { Process } \rightarrow \text { Property }
$$

That is, a SMR - as a property - is an innate part of a soil in its natural state in the environment. Together with the other selected properties, a SMR is part of a discrete concept, a taxon, a classification based on a specific objective (Cline, 1949), and is its own soil entity with lateral boundaries. By analogy, a grassland is an entity with lateral boundaries. A broadleaf deciduous forest is an entity. A wetland is an entity. Likewise, a Udox in Africa is an entity. With climate change, soils classified as Udox will likely shrink as an entity while neighboring soils classified as Ustox will expand as an entity. 
To many pedologists, the concept of Udox as a broad-scale entity, a shrinking entity, conveys more insight than simply overlaying a GIS layer of SMRs.

\section{2 | Conveying information}

Several points need to be made relative to the Shannon diversity approach described above (Figures 4 and 5). First, increasing the number of suborders will always lead to a positive $\Delta H$. For the number of suborders to increase within a grid cell, they must be smaller, which makes it harder to show them on a regional small-scale map. Second, the information normally at the great group level (i.e., calcic, sulfuric, mollic, umbric horizons, duripans, fragipans, and high or low base saturation) has been shifted up a level. What formative elements will go in the great group and subgroup positions to keep those taxa from losing their original concept, especially if SMR was used at two levels? Third, the premise of the approach is to show that in the current taxonomy little information is gained moving from soil order to suborder. However, will the information gained by shifting up that information be lost when moving from suborder to great group or when moving from great group to subgroup?

An important question to consider is whether "general information" associated with SMR equates to relevant information at the suborder level. Soil Taxonomy rests on the foundation that groups are formed for the purposes deemed to be important for a specific objective, such as crop production. For example, the profile of a soil formed in loess in Illinois (udic) may be essentially identical to the profile of a soil formed in loess in eastern Washington (xeric), but the soil in eastern Washington must be irrigated to produce maize (Zea mays L.) and soybeans [Glycine max (L.) Merr.] (Smith, 1983). Soil holds moisture that native plants and crops require. Whether a soil needs to be irrigated is moisture dependent. Soil Taxonomy was developed as a basic classification system for classifying and mapping soils for agricultural purposes. In the guidelines for creating Soil Taxonomy, it is stated that "in deciding between two properties, the soil property that most contributes to agriculture should be given priority" (Soil Survey Staff, 1975).

Natural biomes follow soil moisture patterns. As an example, the boundary between grasslands and forest ecosystems moving west through the central United States is often obvious. Thus, Mollisols are typically found in native grasslands and prairies of the Corn Belt and Great Lakes states and west of the Mississippi River. Similarly, in the western United States, ecosystems change from desert shrubland to grassland to savannah and from savannah to forests as elevation increases with a consequent increase in effective soil moisture. These general soil moisture-plant relationships stress the importance of soil moisture to related issues such as biodiversity, fire management, soil C management, and pedogenesis. These cases point to the fact that soil moisture, not mean annual precipitation alone, contributes to soil and vegetative diversity (Dick-Peddie, 1993; Herbel \& Gile, 1973; Rango, Tartowski, \& Laliberte, 2006; Weems \& Monger, 2012). In other words: "climate within the soil is unlike that above the soil" (Kellogg, 1941). In addition to the extrinsic factors of slope aspect, elevation, runoff-runon conditions, and groundwater inputs, intrinsic soil properties-namely, particle size distribution, organic matter content, pedogenic carbonate, and presence of rock mulch—affect SMR as well (Dick-Peddie, 1993; Duniway, Herrick, \& Monger, 2010; Tejedor, Jimenez, \& Diaz, 2002). Thus, soil moisture is not always climate driven, and at the local level it can also be a function of the location on the landscape. In these instances, the SMR is a dominant feature of the soil system that helps describe its geography, ecology, and pedogenic evolution.

\section{3 | Should SMR be separate from STR in Soil Taxonomy?}

Although it is undeniable that soil moisture is important to ecological and pedogenic processes in soil, some pedologists consider the other component of soil climate, temperature, to be equally important. Smith (1986) noted "Soil moisture and soil temperature are amongst the most important soil properties in controlling the uses of the soil." Soil and air temperature are important as well because they modify the effectiveness of precipitation in changing soil moisture and, consequently, influence the type and quantity of vegetation, rate of organic decomposition, rate of chemical weathering, and freeze-thaw. Soil moisture can be managed by drainage or irrigation, but soil temperature cannot. However, some pedologists point out that temperature exerts less influence on soil properties than moisture (Yaalon, 1983). Soil moisture is more consequential than temperature to diagnostic horizon formation because water is the agent that leaches ions and translocates clay and organic compounds, and like temperature, it influences the type and quantity of vegetation. Evidence that soil moisture is more consequential than temperature for diagnostic horizon formation can be seen by examining the climatic distribution of diagnostic horizons. As stated above, the gypic, salic, calcic, and petrocalcic horizons are rarely found in the udic moisture regime, but these horizons are readily found in the hyperthermic, thermic, mesic, and frigid temperature regimes. Thus, although all agree that consistency is important in a classification system, some suggest that there are distinct advantages to applying SMR at different levels in Soil Taxonomy (Smith, 1986). 


\section{4 | Does the move increase the efficiency Soil Taxonomy?}

One of the goals of making fundamental changes to Soil Taxonomy is to increase the efficiency of the classification process as much as possible without losing any of the information provided in the current system. Moving SMR to the family level can be argued as moving away from this goal, since identifying the moisture regime is an easy step in the classification process. This proposed change would add an additional component to the family level classification, which is arguably the most complex part of the classification already having family particle size, mineralogy, cation exchange, and soil temperature classes. It is likely that this change would greatly increase the number of taxa at the family level.

\section{5 | Resource barriers}

A pragmatic but important consideration is recognizing that if such a change to Soil Taxonomy was to occur, depending on how differentiating characteristics and/or diagnostic horizons are prioritized or introduced in newly developed suborders, great groups, and subgroups, existing USDA-NRCS soil survey products (e.g., SSURGO) could be impacted. This is more likely if soil series are split into two or more new classifications due to the development of new classes within categories. For example, a series that classifies at the subgroup level as a Plinthic Kandiudult potentially could be changed to a Plinthkandult. A logical development for this taxa, in order to provide more information, is to have Oxyaquic (among others) as well as Typic subgroups. As such, some of the Plinthic Kandiudult soils could be reclassified as Oxyaquic Plinthkandults, whereas others would classify as Typic Plinthkandults because they have a deeper water table. Because soil landscapes are correlated to appropriate taxa for the development and delineation of soil map units, changes in classification could require revisiting documentation of existing survey maps for determining dominant and/or percentages of minor components.

In addition, if the proposed restructuring was to occur, it would require a large (huge) effort to rewrite the Keys to Soil Taxonomy (Soil Survey Staff, 2014). As an example, for Alfisols, the key to suborders would need to be rewritten, as would the keys to the Udalfs, Ustalfs, and Xeralfs. Within these pages, the concepts for Torrertic Haplustalfs, Udertic Haplustalfs, Vertic Haplustalfs, Aquic Arenic Hapustalfs, Aquultic Haplustalfs, Aquic Haplustalfs, and Oxyaquic Haplustalfs would have to be reassigned or rewritten because the concept of these soils emphasize borderline soil moisture conditions. Similar rewrites would be necessary for Andisols, Entisols, Inceptisols, Mollisols, Oxisols, Ultisols, and Vertisols.

\section{4 | SUMMARY}

Soil Taxonomy is a tool containing a vast amount of knowledge that enables pedologists, as specialists, the opportunity to help other disciplines understand many soil-related facets of the Earth's surface. All the members of the Fundamental Change Task Force agree that Soil Taxonomy needs to be improved, especially increasing clarity and explaining concepts and the rationale for how taxa were quantified, but what changes are needed within its present architecture are in question. The example approach taken here to change taxonomy at the suborder level is debatable; however, the example clearly illustrates that changes can be made in Soil Taxonomy that would make classification at the suborder more meaningful with regard to diagnostic soil horizons and characteristics and other important soil properties while drastically reducing the number of taxa at the subgroup level. The goal in making fundamental changes is to create a system that more than experienced pedologists can use, and that can serve as an effective and engaging tool for the soil science community to reach and assist other disciplines that use soils information. Moreover, this approach might provide an avenue to increase the use of Soil Taxonomy by other disciplines that need detailed soil property information but do not necessarily need to engage in Soil Taxonomy to the family or series level.

The proposed change could increase the efficiency of soil classification. The perceived downfall of moving SMR to the family level is (a) a deemphasis of the importance of SMR, (b) a major disruption of a hierarchical taxonomic system in which having SMRs at the suborder level provides a broad category from which to subdivide soil taxa into progressively more specific groups, and (c) that the current system works well in certain areas for making soil moisture and vegetation patterns intelligible, such as in environments where ecosystems experience seasonal water stress.

The proposed change would not eliminate SMR but move it to the family level along with its counterpart soil temperature, thus giving the impression that soil temperature and moisture are equally important, and making it necessary to reconceive existing taxa. Soil scientists, agronomists, conservationists, and ecologists understand the fundamental relationships between native and cultured plant communities and soil moisture at the regional and local levels. Recent research (Harvey, 2020), however, suggests that as currently defined, SMR may not adequately convey these relationships. Thus, by emphasizing soil properties other than soil moisture at the suborder level, these users of Soil Taxonomy would benefit from developing an understanding of the relationships between plant communities and other important soil properties. In question, however, is whether moving a property from great group level to suborder level would enable soil scientists, agronomists, conservationists, and ecologists to 
have a greater understanding of relationships between the ecosystem and Eutr, Dystr, Calc, Dur, and Frag than they now have with Soil Taxonomy. Technologies such as GIS, smartphones, and tablets, which were not available when Soil Taxonomy was initially developed, are an excellent mechanism to relay these relationships to the user.

We present arguments for and against a potential change in classification at the suborder level that emphasizes soil properties over SMR, and that reduces the number of taxa at the subgroup level. The proposed change continues to support the use of Soil Taxonomy by more experienced pedologists but emphasizes soil property-specific information sought by users outside of the discipline of soil science, or who do not necessarily want to engage in Soil Taxonomy to the family or series level. Is this the best way to go? Soil scientists east of the 100th meridian may argue that the suggested change increases the efficiency of soil classification without losing any of the current knowledge in the system. Perhaps this argument is because SMR at the suborder level, east of the 100th meridian, is not an effective discriminator of dominant pathways of soil genesis. West of the 100th meridian, soil scientists might argue that SMR at the suborder level simplifies communicating large amounts of information regarding climate as a dominant driver of pedogenesis and soil properties. Thus, the perceived downfall of moving SMR to the family level is a deemphasis on the importance of soil moisture and less clearly and efficiently communicated soil information.

Our goal is an accurate, clear, and efficient Soil Taxonomy for all users. We seek responses to this proposal that present analyses of the proposal's strengths and weakness. Detailed assessments of the proposal's effect on classification of soils and its field application are essential to the comprehensive evaluation of a proposed change and any potential revision. A written record of these communications will facilitate a longterm mechanism of recording the rationale for changes to Soil Taxonomy for future generations.

\section{CONFLICT OF INTEREST}

The authors declare no conflict of interest.

\section{AUTHOR CONTRIBUTIONS}

Mark H. Stolt: Conceptualization; Formal analysis; Writingoriginal draft; Writing-review \& editing. Anthony T. O'Geen: Conceptualization; Formal analysis; Writing-original draft; Writing-review \& editing. Dylan E. Beaudette: Conceptualization; Formal analysis; Writing-original draft; Writingreview \& editing. Patrick J. Drohan: Conceptualization; Formal analysis; Writing-original draft; Writing-review \& editing. John M. Galbraith: Conceptualization; Formal analysis; Writing-original draft; Writing-review \& editing. David L. Lindbo: Conceptualization; Formal analysis; Writingoriginal draft; Writing-review \& editing. H. Curtis Monger: Conceptualization; Formal analysis; Writing-original draft;
Writing-review \& editing. Brian A. Needelman: Conceptualization; Formal analysis; Writing-original draft. Martin C. Rabenhorst: Conceptualization; Formal analysis; Writingoriginal draft; Writing-review \& editing. Michel D. Ransom: Conceptualization; Formal analysis; Writing-original draft; Writing-review \& editing. Joey N. Shaw: Conceptualization; Formal analysis; Writing-original draft; Writing-review \& editing

\section{O R C I D}

Mark H. Stolt (D) https://orcid.org/0000-0003-4037-0498 Anthony T. O'Geen (D) https://orcid.org/0000-0003-1499$511 \mathrm{X}$

Patrick J. Drohan (D) https://orcid.org/0000-0003-3103-7108 Martin C. Rabenhorst (D) https://orcid.org/0000-0002-16647242

\section{R E F E R E N C E S}

Baldwin, M., Kellogg, C. E., \& Thorp, J. (1938). Soil classification. In Soils and men: Yearbook of agriculture (pp. 979-1001). U.S. Government Printing Office.

Buol, S. W., Southard, R. J., Graham, R.C., \& McDaniel, P.A. (2003). Soil genesis and classification. Iowa State University Press.

Bureau of Economic Geology. (2008). General soil map of Texas. University of Texas at Austin. https://agrilifecdn.tamu.edu/brc/files/ 2015/07/General-Soil-Map-of-Texas.pdf

Cline, M. G. (1949). Basic principles of soil classification. Soil Science, $67,81$.

Cline, M. G. (1963). Logic of the new system of soil classification. Soil Science, 96, 17-22.

Cline, M. (1979). Soil classification in the United States (Agronomy Mimeo 79-12). Cornell University.

D’Avello, T., Waltman, W. J., Waltman, S. W., Thompson, J., \& Brennan, J. (2019). Revisiting the Pedocal/Pedalfer boundary and soil moisture regimes using the java Newhall simulation model and PRISM data. Geoderma, 353, 125-132. https://doi.org/10.1016/j.geoderma.2019. 06.042

Dick-Peddie, W. A. (1993). New Mexico vegetation: Past, present, and future. University of New Mexico Press.

Duniway, M. C., Herrick, J. E., \& Monger, H. C. (2010). Spatial and temporal variability of plant-available water in calcium carbonate cemented soils and consequences for arid ecosystem resilience. Oecologia, 163, 215-226. https://doi.org/10.1007/ s00442-009-1530-7

Jenny, H. (1941). Factors of soil formation. McGraw-Hill.

Galbraith, J.M., Stolt, M. H., Rabenhorst, M. C., \& Ransom, M. D. (2018). Impacts of fundamental changes to Soil Taxonomy. South African Journal of Plant and Soil, 35, 263-267. https://doi.org/10. 1080/02571862.2017.1419386

Guo, Y., Gong, P., \& Amundson, R. (2003). Pedodiversity in the United States of America. Geoderma, 117, 99-115. https://doi.org/10.1016/ S0016-7061(03)00137-X

Harvey, A. (2020). An exploratory assessment of soil moisture regime delineations in the Pacific Northwest (Master's thesis, University of Idaho).

Herbel, C. H., \& Gile, L. H. (1973). Field moisture regimes and morphology of some arid-land soils in New Mexico. In R. R. 
Bruce (Ed.), Field soil water regime (Vol. 5, pp. 119-152). SSSA. https://doi.org/10.2136/sssaspecpub5.c7

Isbell, R. F., \& National Committee on Soil and Terrain.(2016) The Australian Soil Classification. CSIRO Publishing. https://www.clw.csiro. au/aclep/asc_re_on_line_V2/soilhome.htm

IUSS Working Group. (2015). World Reference Base for soil resources 2014, update 2015: International soil classification system for naming soils and creating legends for soil maps (World Soil Resources Reports 106). FAO.

Kellogg, C. E. (1941). Climate and soil. In G. Hambidge (Ed.), Climate and man: Yearbook of agriculture (pp. 265-291). U.S. Government Printing Office.

Krasilnikov, P., Ibanez Marti, J., Arnold, R., \& Shoba, S. (2009). Handbook of soil terminology, correlation, and classification. Routledge.

Legendre, P., \& Legendre, L. (1998). Numerical ecology. Elsevier.

Marbut, C. F. (1935). Atlas of American agriculture: Part III. Soils of the United States. U.S. Government Printing Office.

Newhall, F., \& Berdanier, C. R. 1996. Calculations of soil moisture regimes from the climatic record (Soil Survey Investigation Report 46). National Soil Survey Center.

Rabenhorst, M. C. (2016). A half-century on changes in Soil Taxonomy. Soil Science Society of America Journal, 80, 839-844. https://doi.org/ 10.2136/sssaj2016.02.0046

Rango, A., Tartowski, S. L., \& Laliberte, A. (2006). Islands of hydrologically enhanced biotic productivity in natural and managed arid ecosystems. Journal of Arid Environments, 65, 235-252. https://doi. org/10.1016/j.jaridenv.2005.09.002

Ricotta, C., \& Szeidl, L. (2006). Towards a unifying approach to diversity measures: Bridging the gap between the Shannon entropy and Rao's quadratic index. Theoretical Population Biology, 70, 237-243. https://doi.org/10.1016/j.tpb.2006.06.003

Riecken, F. F., \& Smith, G. D. (1949). Lower categories of soil classification: Family, series, and phase. Soil Science, 67, 107-115.

Salley, S. W., Sleezer, R. O., Bergstrom, R. M., Martin, P. H., \& Kelly, E. F. (2016). A long-term analysis of the historical dry boundary for the Great Plains of North America: Implications of climatic variability and climatic change on temporal and spatial patterns in soil moisture. Geoderma, 274, 104-113. https://doi.org/10.1016/j.geoderma.2016. 03.020

Schaetzl, R. J., \& Anderson, S. (2005). Soils: Genesis and geomorphology. Cambridge University Press.

Shannon, C. E., \& Weaver, W. (1949). The mathematical theory of communication. University of Illinois Press.

Simonson, R. W. (1997). Evolution of soil series and type concepts in the United States. In D. H. Yaalon \& S. Berkowicz (Eds.), History of soil science: International perspectives. Advances in Geoecology Vol. 29 (pp. 79-108). Catena.

Smith, G. D. (1963). Objectives and basic assumptions of the new classification system. Soil Science, 96, 6-16.

Smith, G. D. (1983). Historical development of Soil Taxonomy: Background. In L. P. Wilding, N. E. Smeck, \& G. F. Hall (Eds.), Pedogenesis and Soil Taxonomy: Concepts and interactions (Vol. 11A, pp. 23-49). Elsevier.
Smith, G. D. (1986). The Guy Smith interviews: Rationale for concepts in Soil Taxonomy. USDA.

Soil Classification Working Group (SCWG). (1998). The Canadian system of soil classification. NRC Research Press.

Soil Survey Staff, (1975). Soil Taxonomy: A basic system of soil classification for making and interpreting soil surveys (1st ed.). U.S. Government Printing Office.

Soil Survey Staff, (1999). Soil Taxonomy: A basic system of soil classification for making and interpreting soil surveys (2nd ed.). U.S. Government Printing Office.

Soil Survey Staff. (2014). Keys to Soil Taxonomy (12th ed.) USDANRCS.

Soil Survey Staff. (2020). Survey Geographic (SSURGO) database. USDA-NRCS.

Spaargaren, O. C. (2000). Other systems of soil classification. In M. E. Summer (Ed.), Handbook of soil science (pp. E-137-E-174). CRC Press.

Stolt, M. H., \& Needelman, B. A. (2015). Fundamental changes in Soil Taxonomy. Soil Science Society of America Journal, 79, 1001-1007. https://doi.org/10.2136/sssaj2015.02.0088

Tandarich, J.P., Darmody, R. G., Follmer, L. R., \& Johnson, D. L. (2002). Historical development of soil and weathering profile concepts from Europe to the United States of America. Soil Science Society of America Journal, 66, 335-346. https://doi.org/10.2136/sssaj2002.3350

Targulian, V. O., \& Goryachkin, S. V. 2004. Soil memory: Types of record, carriers, hierarchy and diversity. Revista Mexicana de Ciencias Geológicas, 21, 1-8.

Tejedor, M., Jimenez, C. C., \& Diaz, F. (2002). Soil moisture regime changes in tephra-mulched soils: Implications for Soil Taxonomy. Soil Science Society of America Journal, 66, 202-206. https://doi.org/10. 2136/sssaj2002.2020

Troeh, F. R., \& Thompson, L. M. (2005). Soils and soil fertility. WileyBlackwell.

Weems, S. L., \& Monger, H. C. (2012). Banded vegetation-dune formation in the Medieval Warm Period and 20th century, Chihuahuan Desert, New Mexico, USA. Ecosphere, 3(3). https://doi.org/10.1890/ ES11-00194.1

Winzeler, H. E., Owens, P. R., Waltman, S. W., Waltman, W. J., Libohova, Z., \& Beaudette, D. (2013). A methodology for examining changes in soil climate geography through time: U.S. soil moisture regimes for the period 1971-2000. Soil Science Society of America Journal, 77, 213-225. https://doi.org/10.2136/sssaj2012.0123

Yaalon, D. H. (1983). Climate, time, and soil development. In L. P. Wilding, N. E. Smeck, \& G. F. Hall (Eds.), Pedogenesis and soil taxonomy: Concepts and interactions (Vol. 11A, pp. 233-251). Elsevier.

How to cite this article: Stolt MH, O'Geen AT, Beaudette DE, et al. Changing the hierarchical placement of soil moisture regimes in Soil Taxonomy. Soil Sci Soc Am J. 2021;85:488-500. https://doi.org/10.1002/saj2.20219 